reason is not fortified with the same serene philosophy as Russell's.

Notably is this true when Prof. Carr writes of the international scene and of the road to freedom. He stimulates thought. He stresses some, but not all, of the factors that must be taken into account if we are to build a new world. $\mathrm{He}$ is no iconoclast and believes that it is possible to build fresh achievements on those of the nineteenth century; but his idea of the limits and potentialities of science and technology is neither as clear nor as comprehensive as that of Earl Russell, and he does not really face the contradictions between individualism, social responsibility and political or economic power of which he is well aware and which must be resolved in formulating either a social philosophy or a science of politics. One looks again for some indication as to what is to be the cement that will hold together the fabric of the new society.

For all these limitations, both books are to be read and pondered. They give us no facile pattern of a new world or society; but they could contribute to the critical insight, to the revision of judgments, and to the weighing of values which are part of the creative thought which must precede the shaping and making of a new world. They challenge the prevailing timidity, conservatism and restrictionism for which Prof. Carr in particular pillories contemporary Britain; and in sombre days they summon men and women to be worthy of their heritage of the past and to face the future with confidence, uninhibited and unafraid.

R. Brightiman

\section{NEW MONOGRAPHS ON PHYSICS} The Earth's Magnetism

By Prof. Sydney Chapman. (Methuen's Monographs on Physical Subjects.) Second edition, revised and reset. Pp. xi+128. (London: Methuen and Co., Ltd.; New York: John Wiley and Sons, Inc., 1951.) 6s. net.

\section{Semi-Conductors}

By D. A. Wright. (Methuen's Monographs on Physical Subjocts.) Pp. viii+130. (London : Methuen and Co., Ltd.; New York: John Wiley and Sons, Inc., 1950.) 7s, 6d. net.

\section{Photons and Electrons}

By K. H. Spring. (Methuen's Monographs on Physical Subjects.) Pp. viit 108. (London: Methuen and Co., Ltd. ; New York : John Wiley and Sons, Inc., 1950.) $7 s .6 d$. net.

An Introduction to Electron Optics

By Dr. L. Jacob. (Methuen's Monographs on Physical Subjects.) Pp. $x+150$. (London: Methuen and Co., Ltd.; New York: John Wiley and Sons, Ine., 1951.) $8 s .6 d$. net.

\section{Introduction to Servomechanisms}

By Dr. A. Porter. (Methuen's Monographs on Physical Subjects.) Pp. vii+154. (London: Methuen and Co., Ltd. ; New York: John Wiley and Sons, Inc., 1950.) $7 s .6 d$. net.

T HE series of "Methuen's Monographs on Physical Subjects" is a boon to honours and postgraduate students and to many research workers in physics and allied branches of science. The monographs provide an up-to-date introduction to modern developments and new techniques. In this they supplement and anticipate the text-books. Their authors are either engaged in research on the subjects about which they write, or are highly skilled in the use of the methods and techniques which they describe. The reader is expected to have had a good scientific training though not necessarily in the particular branch of physics discussed. The language used is technical and mathematical.

The monographs under review are five recent additions to the series. One only is not new : this, "The Earth's Magnetism", by Prof. Sydney Chapman, is a revised and completely reset edition. Prof. Chapman, by avoiding the mathematical developments of the subject and such cognate topics as radio research, itself worthy of a monograph, has managed to give a brief but broad account of the earth's magnetic field and its changes. The new diagrams and the magnetic charts for 1945 will be found particularly useful. In spite of the detailed knowledge that is now available concerning the earth's magnetism, it would appear that its origin is still a matter of uncertainty.

Three monographs deal with phenomena connected with electrons. "Semi-Conductors", by D. A. Wright, is concerned mainly with the density and flow of electrons in metals, crystals and semi-conductors and with the emission of electrons from these substances. The treatment is largely descriptive and deals with work up to about the middle of 1949. For example, the transistor is given barely four pages. "Photons and Electrons", by K. H. Spring, gives a brief account of the main ways in which electrons interact with radiation. The photoelectric effect, the Compton effect, the production of X-rays, the formation of electron pairs and certain aspects of cosmic-ray phenomena are separately discussed. Both monographs suffer from minor errors in units and mathematical expressions.

The fourth monograph, "Electron Optics", by Dr. L. Jacob, is an attempt to state the principal laws governing the motion of charged particles through electric and magnetic fields. The close analogy between light opties and electron optics is stressed, and it is assumed that the reader is familiar with simple optical devices. Though published in 1951, the foreword to the monograph is by the late Sir Clifford C. Paterson and is dated March 1947. The otherwise good bibliography to the monograph is marred by the unorthodox abbreviations used for the titles of the journals quoted. The abbreviations are difficult to interpret and no key to them is provided.

The last of the five monographs, that on servo mechanisms, by Dr. A. Porter, is rather different in character from the other four, in that, first, it is based on a course of lectures given by the author while professor of instrument technology at the Military College of Science, Shrivenham, to army officer students studying engineering physics; and, second, it is scarcely likely that physics students, unless and until they enter industry, will need to have any knowledge of the subject of servomechanisms. Though there are some notes on non-linear problems, it is mainly linear servo systems which are dealt with, and the steady-and transient-state behaviours of these are considered. The Laplace transformation is not used. The aim is to lay emphasis on the physical principles and to avoid mathematical complication. Nevertheless, the physies stutent will find the going rather difficult, and perhaps in this connexion the title "Introduction" is misleading.

S. WeintrodB 